\title{
The Main Problem and Countermeasure Research on Disabled Children's Right to Education in Poor Areas
}

\author{
Rongna Zhe \\ School of Law \\ Sichuan University \\ Chengdu, China
}

\begin{abstract}
In domestic law, the right on disabled children mainly involves Disability Act of the People Republic of China and People with Disabilities Education Ordinance. However, the implementation of these laws and policies is not satisfactory. The aim of this paper contributes to improve relevant policy and develop special education in poor area. This Article raises two main questions: first what the main problem of disabled children's education in the poor area and second what are countermeasure for the education of disabled children education. The significance of this analysis has to do with helping readers to understand the problems and find out policy measures, such as promote the spread of special education idea and continue to implement the preferential policies about the poor areas. ${ }^{1}$
\end{abstract}

Keywords-poor areas; disable children; the right to education

\section{INTRODUCTION}

In November 2013, The Central Committee of the Communist Party of China on several major issues of comprehensive reform decision pointed out: "We should vigorously promote the equity in education, complete funding system for students from poor families, build an effective information technology to expand the coverage of high-quality educational resources, to gradually narrow regional, rural and urban, inter-school gap."2

The equal right to education of disabled children in poor area is an important part on the construction of the harmonious society in China. Enhancing the protection of the right to education in poor areas's disabled children is not only the urgent needs of sharing equal education opportunities and educational resources for the poor children with disabilities, but also objective request to improve the efficiency of poverty alleviation in poor areas and to raise awareness of the national community.

Foundation item: The National region's development obstacle and legal countermeasure research in the construction of National park. National research projects of State Ethnic Affairs Commission in 2017(Item number: 2017-GMB-028).

\footnotetext{
Doctoral candidate of The Law School of Sichuan University.

The central committee of the communist party of China on some major problems comprehensively deepen reform decision.
}

In recent years, the party and the country attached great importance to the right of education for marginalized groups, and formulated a series of policies. In 2011, disabled Working Committee of the State Council formulated the "Development Program of the cause of the china disabled persons in the twelfth five year period (2011-2015)". The State Council General Office forwarded "The State Council on Forwarding the Special Education Enhancement Program of education ministry (2014-2016 year) (2014) No. 1" and so on.

How effective are these policies in poor disability groups implemented? What difficulties are faced in the implementation process? What are the wishes and aspirations of the disabled children and their guardians in poor areas? To clear these questions are the premise basis and the important part to the further improving of the relevant policies and the implementation of equal right for disabled children in poor areas.

\section{The MaIN PROBlems EXISTING IN THE}

IMPLEMENTATION OF EDUCATION POLICY FOR DISABILITIES

$$
\text { IN POOR AREAS }
$$

At present, with the government's consciousness of continuous development, educational situation in the poor area has been continuously improved, and the educational level of the handicapped children has also been improved.

Article 17 of Regulations on the education of the disabled states: "The school-age disabled children and teenagers receive compulsory education in the following forms:

- Mainstreaming in regular schools;

- Attending special education classes in ordinary schools, child welfare agencies or other bodies attached to disability children, adolescents;

- Study in special education schools for disabled children and teenagers. "

As we can see, there are three ways to place disabled education in our country's law: converged mode, attached formula and isolated.The local economic development level, the school infrastructure and the teachers' professional ability 
are limited in the poor region. So, the basic mode of education for disabled children is the converged mode.

With the implementation of the country's western development projects, educational resources are inclined to remote rural nation, poverty-stricken areas, education fair progress has been made. However, in the implementation process of educational policy in the poor areas, there are still many problems and need to be solved, including: scarce special education schools in the poor region, a serious shortage of funding for education of children with disabilities in the poor areas, poor construction of education personnel in poor area, imperfect legal system related to education for disabled children and other objective factors.

\section{A. Serious Shortage of Education Funding for Disabled Children in Poor Areas}

CPC Central Committee and State Council on "Longterm Education Reform and Development Plan (2010-2020)" should be made to continue to increase investment in education, to reach $4 \%$ in 2012 . However, because China's vast land area, there are different degrees of difference in government investment in education funding. According to the student education funding and teach welfare wages, the gap between east area and west area is still large. "

\section{B. Extremely Poor Team Building of Special Education \\ Personnel in Poor Areas}

Poor economic backward areas with hard living condition are lack of school excellent teachers, especially professional personnel of special education. Teachers in poor rural schools often play multiple roles, including serving as special education teachers. As for teacher's special talent team construction, there are many acute problems, such as loopholes in education arrangement, extreme shortage of bilingual teachers, low quality of special education teachers, unreasonable management system with poor wage, heavy task and so on.

1) Loopholes exist in education arrangements: Special education schools currently only accept students of specific types (physical disabilities or mild visual disabilities) and with the ability to self-care.A direct result is that a number of students with severe disabilities can only drop out school.

The economic conditions of families with disabled children in poor rural areas is difficult, and the school only at the state level can create a special education school, so that special education is unrealizable for most villagers who did not even leave this village because of distance and high tuition fee which led numerous severely disabled children drop out school in poor rural areas directly.

Sadly, these highly disabled rural children in poor area generally passed away prematurely. Learning in the regular classroom for disabled children in poor areas is an ideal education model, but no government or school care for the education problem of rural children with severe disabilities.

2) The teachers have low attainments in special teaching: In the poor area, rural schools have no teachers skilled in special teaching, so this work is always done by usual administrative staff. But it results that those teachers who have no knowledge background of special teaching, have no time to attend the cultivation of students with disabilities. Many teachers in poor areas do not know how to face disabled children, and even worried about that the disabled children will adversely affect classmates, dragging down the overall class results.

\section{Disabled Children's Special Education Legislation Is More Dispersed, Low-level in Special Legislation}

As can be seen, in all of the law on special education for children with disabilities, the fundamental law is constitutional, Article 46 stipulates: "The state and society help make arrangements for blind, deaf mutes and other handicapped citizens' work, life and education."

In addition, Protection of Disabled Persons "referred in Article $21^{3}$, for children with disabilities, whose families are in poor areas, the government should provide free textbooks and boarding subsidies for living expenses and so on; at the same time, when help people with disabilities to be ideological, cultural, educational, also strengthen the physical and psychological compensation; enrollment and teaching age of special education may have elasticity. ${ }^{4}$ In Compulsory Education Law, Article 6 stipulates that local governments above the county level should protect children with disabilities from poor families in the poor and minority areas to receive compulsory education; Article 19 provides that ordinary schools should accept Mainstreaming children with disabilities who have the attendant capabilities and assist their learning and rehabilitation. ${ }^{5}$ In Protection of Minors Act, Article 28 stipulates that governments at all levels should guarantee the disabled minors of economically disadvantaged families in poor areas to receive education. ${ }^{6} \mathrm{In}$ Education Law, Article 38 stipulates that the state, society and schools should provide education in accordance with the physical and psychological situation of children with

\footnotetext{
${ }^{3}$ Article 21, <Protection of Disabled Persons>: governments at all
} levels provide compulsory education for students with disabilities, students of poor disabled families free textbooks and boarding expenses allowance; provide students with disabilities and those in poor families other than compulsory education with funding, in accordance with relevant state regulations. Article 23: while conduct ideological education, cultural education, strengthen the physical and psychological compensation and vocational education; special education curriculum, teaching materials, teaching methods, entrance and school age, can have appropriate flexibility.

${ }^{4}<$ Compulsory Education Law> Article 6: The State Council and local governments above the county level shall rationally allocate educational resources to promote balanced development of compulsory education, to improve conditions in weak schools, and to take measures to make sure the implementation of compulsory education in rural areas and ethnic minority areas, to protect families with financial difficulties and disabled children and adolescents of school-age to receive compulsory education. Article 19: General school-aged children with disabilities should have received general education capacity, juvenile regular classes, providing help for his learning and rehabilitation.

5 <Protection of Minors Act> Article 28: People's governments at various levels shall safeguard the rights of minors to education, and to take measures to protect the minors of poor families, disabled and migrants to receive compulsory education.

${ }^{6}<$ Education Law>Article 38: The State, society, schools and other educational institutions should base the mental disabilities and the need to implement education, providing the disabled with assistance and convenience. 
disabilities. It can be seen the right to education of children with disabilities are given special legal provisions to regulate. It is in low-level legislation, tending to be interfered by the higher law.

Besides the conditions of hardware facilities, the education for the disabled children in the poor areas still face many more subjective factors, such as the hysteretic concept from their parents, the difficulties of removing the identification badge, the general inferiority of the handicapped children themselves.

\section{THE COUNTERMEASURES TO EDUCATION OF THE DISABLED CHILDREN IN THE POOR AREA}

\section{A. To Improve the Government's Existing Funding Policies, and Actively Solve the Problem of Education Funding for the Disabled Children in Poor Areas}

To further implement the existing policy of capital investment projects, make clear and confirm the special funds and investment funds for disabled children education in remote and poor areas.

To increase student aid for the families facing to economic difficulties, continue to start the "nutrition improvement plan" for poverty-stricken areas. We should implement the stipulate of "The development outline of the12th Five-Year" for the cause of the disabled in China". Implementation of sunshine supporting student program: Providing assistance to the poor and disabled children in preschool education and rehabilitation education

\section{B. To Carry All-round out a Special Education Mode of Joining a Regular Class for Disabled Children.}

To send the education to the doors for those disabled children who can't go to school. The remote areas face much inferior strength, such as backward economy, steep terrain, extremely terrible traffic, less population etc. With the local economic conditions, the number of population and geographical environment, it is inconsistent to establish the individual school especially to the disabled children, it is also irreconcilable with the trends in the integration of international mainstream education for the children with disabilities.

For those children with severe disabilities who can't go to school, schools and governments can arrange specific teachers to send education to their home and offer these teachers allowance. This can not only impart knowledge but also can be advantageous to physical rehabilitation and psychological counseling for children with severe disabilities

\section{To Strengthen the Construction of Special Education Talents in Poor Areas}

- To conscientiously implement the outline of the national medium and long term educational reform and development plan (2015-2020), which requires "The teacher training funds should be included in the budget", "all teachers should be conducted to participate in training every 5 years.", in the aim of
"By 2020, form a team of sufficient quantity, reasonable structure, excellent quality, caring and special education teachers. To improve the structure of teaching teams. By encouraging policies and incentives, to attract college graduates to teach in rural schools in poor rural areas of $\mathrm{Yi}$ ethnic, to enrich the teachers of the Yi mountain area in poverty.

- To try legislation for special education, and to strengthen the implementation of related law and policy. At present, although our country has already formed a series of special education legal system in horizontal and vertical direction.there are still some problems existing such as Lag of legislation conflict, the rules are over principled, the subject of responsibility is not clear. A special legal system should be enacted.

We should focus on the vulnerable groups of people with disabilities, to formulate policies and implement them, to create a good social environment for the disabled to integrate into the community.

\section{CONCLUSION}

This paper analyse possible obstacles on disabled children's right to education in poor areas, such as the special education idea lag, the funds shortage, special education infrastructure are not completed, and the number of qualified special teachers is insufficient in poor area. This explain the need to improve the government's existing funding policies, actively solve the problem of education funding for the disabled children in poor areas, take relevant measures such as cultivate professional special educational teacher, build a "No discrimination" and impartial environment are constituted by family, society and school.

\section{REFERENCES}

[1] Wang Peifeng: "Special education policy:justice and limitation", Nanjing University Press, 1st October 2015

[2] Hao Deyuan, Hao Tianci: "Special education", Capital Normal University Press, 1st November 2010.

[3] Huang Peiseng: "The history of Chinese special education", Southwest Jiaotong University Press, 1st August 2015.

[4] Peng Xiaguang: "China's current situation of special education research's development", China's special education, 11st November 2013.pp.3-7.

[5] Liu Xiaoxiao: "The present situation investigation of Special education website ----based on the comparative analysis of seven education website", Education modernization, April 2017.pp.205-206.

[6] Zhao Xiaohong: "The development and policy suggestion of special education since China's reform and opening up", China's special education, October 2008.pp.36-38. 